\title{
Universiteit
}

Leiden

The Netherlands

\section{Dissolution Dynamics and Accumulation of Ag Nanoparticles in a Microcosm Consisting of a Soil-Lettuce-Rhizosphere Bacterial}

Community

Wu, J.; Zhai, Y.; Liu, G.; Bosker, T.; Vijver, M.G.; Peijnenburg, W.J.G.M.

\section{Citation}

Wu, J., Zhai, Y., Liu, G., Bosker, T., Vijver, M. G., \& Peijnenburg, W. J. G. M. (2021).

Dissolution Dynamics and Accumulation of Ag Nanoparticles in a Microcosm Consisting of a Soil-Lettuce-Rhizosphere Bacterial Community. Acs Sustainable Chemistry And Engineering, 9(48), 16172-16181. doi:10.1021/acssuschemeng.1c04987

Version: Publisher's Version

License: $\quad$ Creative Commons CC BY-NC-ND 4.0 license

Downloaded from: https://hdl.handle.net/1887/3246927

Note: To cite this publication please use the final published version (if applicable). 


\title{
Dissolution Dynamics and Accumulation of Ag Nanoparticles in a Microcosm Consisting of a Soil-Lettuce-Rhizosphere Bacterial Community
}

\author{
Juan Wu, Yujia Zhai,* Gang Liu, Thijs Bosker, Martina G. Vijver, and Willie J. G. M. Peijnenburg
}

Cite This: ACS Sustainable Chem. Eng. 2021, 9, 16172-16181

Read Online

ABSTRACT: Assessment of chronic impact of metallic nanoparticles (NPs) in soil ecosystems is a necessity for ensuring safe and sustainable application. NPs affect plants and their associated microbial life, while the plants and their associated microbiota affect the NPs' fate. Here, we measured the available Ag pool (determined as diethylenetriaminepentaacetic acid-extractable $\mathrm{Ag}$ ) in AgNP-amended sandy loam soil (1, 10, and $50 \mathrm{mg} \mathrm{Ag}$ per $\mathrm{kg}$ of soil) over a period of $63 \mathrm{~d}$ with and without lettuce. The associated impacts on soil $\mathrm{pH}, \mathrm{Ag}$ accumulation in lettuce, and the responses of the rhizosphere bacterial community were determined. We found that the addition of AgNPs significantly increased the soil $\mathrm{pH}$ from 7.70 to 7.87 after a short-term $(7 \mathrm{~d})$ incubation. Noteworthily, the extractability of $\mathrm{Ag}$ in AgNP-amended soil was concentration-dependent and changed over time because of their continuous dissolution and uptake by plants. Ag uptake and upward translocation in lettuce positively correlated with the extractable Ag content in soil. Furthermore, a long-term (63 d) exposure to $50 \mathrm{mg} / \mathrm{kg}$ of AgNPs altered the structure and composition of the rhizosphere bacterial community potentially by regulation of bacterial groups associated with element (e.g., $\mathrm{N}$ and $\mathrm{S}$ ) cycling and stress tolerance. In conclusion, our results demonstrated that the dynamic dissolution of AgNPs in sandy loam soil plays an important role in influencing the overall Ag bioavailability of the NPs in plants. The enhanced effects of AgNPs on the alterations in the rhizosphere bacterial community highlight that the long time-resolved dynamics of NP exposure should be taken into consideration for accurate ecological risk assessment of NPs in the soil ecosystem.

KEYWORDS: silver nanoparticles, plant, bioavailability, agrochemical, rhizosphere soil bacteria

\section{INTRODUCTION}

The rapid development of nanotechnology over the past two decades has inspired the production and application of nanoagrochemicals, and claims have been made that these nanoagrochemicals can improve the sustainability of agriculture. ${ }^{1,2}$ As more and more nano-agrochemicals are introduced in agriculture as fertilizers or pesticides, agricultural soil is inevitably becoming an important sink for nanomaterials. ${ }^{3}$ Silver nanoparticles (AgNPs) are one of the most extensively used commercialized nanomaterials worldwide, and the global production of AgNPs will reach a value of USD 2.45 billion by 2022. ${ }^{4,5}$ Given their excellent antimicrobial properties, they have shown great potential in crop protection as insecticidal agrochemicals and against plant pathogens (phytopathogenic fungi, bacteria, and viruses). ${ }^{1}$ This makes the impact assessment of AgNPs in soil ecosystems a necessity for the safe and sustainable usage of nanoscale products.

The impacts of metallic nanoparticles (NPs) on soil ecosystems have been reported to largely depend on their bioavailable fractions. ${ }^{6}$ For instance, $\mathrm{Pu}$ et al. ${ }^{6}$ reported that the toxicity of $\mathrm{CuO}$ NPs in maize plants and microbes was mainly modulated by the gradually released bioavailable $\mathrm{Cu}$ concentration. Soil properties are known to be a key factor affecting the bioavailability of metallic NPs in natural soil., An important property is the soil $\mathrm{pH}$, which modulates the bioavailability of metallic NPs by affecting the oxidation, aggregation, transformation, and dissolution processes of metallic NPs in the soil. ${ }^{9,10}$ Importantly, plants, a key component of soil ecosystems, ${ }^{11}$ can alter the soil properties directly by themselves or indirectly by the interaction with NPs. For instance, the amount of soil organic material in soil can be influenced by the presence of plants as nearly $5-40 \%$ of the photosynthetically fixed carbon is transported to the rhizosphere by plant root exudates. ${ }^{12}$ Moreover, the interaction between plant roots and metallic NPs can alter the abundance and composition of root exudates and the soil $\mathrm{pH}^{12-14}$ Soil

Received: July 23, 2021

Revised: November 9, 2021

Published: November 18, 2021 
organic matter and root-secreted chelators (such as phytosiderophores) can immobilize/sequester NPs and the released metal ions. ${ }^{15,16}$ These changes in the soil environment may modify the available pool of Ag derived from AgNPs and in turn influence the plant responses. ${ }^{13,17}$

However, to our knowledge, the information regarding how plant roots influence the labile pool of $\mathrm{Ag}$ in a AgNP-amended rhizosphere and the consequent relationship with Ag accumulation in plants is scarce. Recently, Pradas del Real et al. ${ }^{18}$ used diethylenetriaminepentaacetic acid (DTPA) and $\mathrm{CaCl}_{2}$ extractions to assess the lability of $\mathrm{Ag}$ in soil mixed with AgNP-containing sludges $(18-400 \mathrm{mg} / \mathrm{kg}$ ) at a single-time point ( 4 weeks). The authors demonstrated that the low $\mathrm{Ag}$ content in wheat is consistent with the low lability of $\mathrm{Ag}$ in soil. ${ }^{18}$ However, it should be noted that plant growth over time can dynamically change the soil environment and thus the dynamic particle dissolution, which may make the bioavailable Ag concentration time-dependent. ${ }^{19,20}$ To capture these dynamics and their impacts on ecosystems, experiments of longer timescales need to be performed in which a series of time points are included at which the bioavailability of $\mathrm{Ag}$ in soil is assessed in a toxicity assay.

Similar to plants, soil bacteria also play an important role in soil ecosystems by promoting soil fertility and governing soil biological processes such as nutrient transformation and cycling and energy flow. ${ }^{21,22}$ The impacts of AgNPs on bacterial communities of unplanted soil have been extensively reported with inconclusive findings. ${ }^{21-25}$ It is suggested that the responses of the soil microbial community to AgNPs depend on the soil properties, exposure concentration, exposure duration, and the behavior of AgNPs in soil. ${ }^{24,25}$ Therefore, the alterations in the soil environment induced by plants may modify the impacts of AgNPs on the behavior of rhizosphere soil bacteria, ${ }^{26}$ which may result in either detrimental or beneficial impacts on the soil ecosystem. ${ }^{15,17,27}$ To date, little information is available about how AgNPs alter rhizosphere soil bacterial communities. ${ }^{14,28,29}$ This is surprising because it is known that soil rhizosphere bacteria play a crucial role in supporting the host plant growth by regulating nutrient uptake and to some extent by supporting against environmental stressors. ${ }^{27,30}$ Thus, long-term impacts of AgNPs on the rhizosphere soil bacterial community deserve more investigation.

In this study, lettuce plants, a popular representative of the leafy vegetables worldwide, were exposed to $0,1,10$, and 50 $\mathrm{mg} / \mathrm{kg}$ of AgNPs over a period of $63 \mathrm{~d}$. The objectives of this study are (a) to investigate if and to what extent the plants and AgNPs affect the soil $\mathrm{pH}$ and how this impacts the (potentially) available $\mathrm{Ag}$ concentrations shedding from AgNPs, (b) to quantify Ag accumulation and translocation in a soil-plant system, and (c) to determine the alterations of the rhizosphere soil bacterial community structure in response to exposure to AgNPs as a function of exposure concentration and exposure time. This study provides useful information to correlate the time-related changes of bioavailable Ag from AgNP-amended soil with the plant growth and soil microbial communities. Such information is important for risk assessment of nanomaterials in soil ecosystems and for safely and sustainably applying nanoenabled agrichemicals.

\section{MATERIALS AND METHODS}

Silver Nanoparticles. Stock suspensions of spherical AgNPs (NM-300K) with a nominal diameter of $15 \mathrm{~nm}$ and a concentration of
$100 \mathrm{~g} / \mathrm{L}$ were provided by RAS AG (Regensburg, Germany). Physicochemical properties and information on the characterization of the AgNPs are summarized in the JCR reports. ${ }^{31}$ AgNP suspensions at 1,10 , and $50 \mathrm{mg} / \mathrm{L}$ were prepared by diluting the AgNP stock in a $1 / 4$ Hoagland solution $(\mathrm{pH} 6.0 \pm 0.1)$. The composition of the Hoagland solution is described in Table S1 (Supporting Information). The suspensions were sonicated for $5 \mathrm{~min}$ at $60 \mathrm{~Hz}$ (USC200T, VWR, Amsterdam, The Netherlands). The freshly prepared suspensions were used to determine the size distribution and zeta potential with a Zetasizer Nano-ZS instrument (Malvern, Instruments Ltd., Royston, UK) at 1, 24, and $48 \mathrm{~h}$ of incubation. The data are published in our previous publication ${ }^{11}$ and provided in Table S2. The transmission electron microscopy (TEM) picture of the AgNPs is also provided in Figure S1 (Supporting Information).

Soil Preparation. Surface agricultural soil $(0-20 \mathrm{~cm})$ was collected from a nonpolluted site $\left(52^{\circ} 10^{\prime} 16.8^{\prime \prime} \mathrm{N} 4^{\circ} 26^{\prime} 58.9^{\prime \prime} \mathrm{E}\right.$, Leiden, The Netherlands), mixed thoroughly, sieved to $2 \mathrm{~mm}$ after being air-dried, and stored at $4{ }^{\circ} \mathrm{C}$ before use. The soil was sandy loam with a $\mathrm{pH}$ of 8.4 in water and 7.4 in the $\mathrm{KCl}$ solution, containing $2.2 \%$ of organic carbon, with a clay content of $18.4 \%$ and a cation exchange capacity of $0.39 \mathrm{cmol}^{(+)} \mathrm{kg}^{-1}$. No Ag (< detection limit) was detected in the untreated soil. The exchangeable cations content and the content of various metals were determined, and these properties are reported in Table S3.

Plant Growth and Exposure Assay. Lactuca sativa seeds (Floveg GmbH, Kall, Germany) were first sterilized for $5 \mathrm{~min}$ in $0.5 \%(\mathrm{w} / \mathrm{v}) \mathrm{NaClO}$, followed by rinsing 3 times with tap water and immersing for $24 \mathrm{~h}$ in tap water. Afterward, the seeds were germinated in Petri dishes filled with a wet filter paper (15 seedlings/dish). After $3 \mathrm{~d}$, the $1 / 4$ Hoagland solution was added into the Petri dishes to supply nutrients for seedling growth. After pregrowing in Petri dishes for 1 week, the young seedlings were transferred to bottles (one seedling per bottle) with a height of $15 \mathrm{~cm}$ containing the Hoagland solution for further 2 weeks of growth. The suspensions in the Petri dishes and bottles were refreshed every $3 \mathrm{~d}$.

The AgNP suspensions were prepared in the $1 / 4$ Hoagland solution and sonicated at $60 \mathrm{~Hz}$ for $15 \mathrm{~min}$ before application to soil. Afterward, the AgNP suspensions were added to soil to achieve the nominal concentrations of 1,10 , and $50 \mathrm{mg} \mathrm{Ag}$ per $\mathrm{kg}$ of soil. The exposure concentrations of AgNPs were chosen based on the predicted and measured concentration of AgNPs in sludge/ biosolids. ${ }^{18}$ The soil was mechanically stirred with a mixer for 15 min to homogenize the AgNPs. Control treatment was the same as the AgNP treatments with the addition of the same volume of the $1 / 4$ Hoagland solution. Next, two uniform pregrown seedlings were transferred into one plastic pot $(9 \mathrm{~cm}$ long, $9 \mathrm{~cm}$ wide, and $9.5 \mathrm{~cm}$ high) containing $0.5 \mathrm{~kg}$ of AgNP-amended soil or clean soil. Treatments with 1,10 , or $50 \mathrm{mg} \mathrm{Ag}$ per $\mathrm{kg}$ of soil but without plants were also performed under the same conditions. In brief, this experiment consisted of three components: (a) AgNP application dose $(0,1,10$, and $50 \mathrm{mg} / \mathrm{kg})$, (b) exposure time (3-63 d), and (c) the presence or absence of plants for a total of 17 treatments in triplicate, as described in Table S4. The pots were watered every $2 \mathrm{~d}$, and all pots were placed in a climatic room under the conditions of day/night with a temperature of $20 / 16^{\circ} \mathrm{C}$ and a light/dark cycle of $16 / 8 \mathrm{~h}$ with $60 \%$ relative humidity until harvest. After each exposure time point, the plants in each pot were harvested, and subsequently, the nonrhizosphere soil (further referred to as bulk soil) and soils with rhizospheres (further referred to as rhizosphere soil) were collected.

Plant Harvesting and Soil Sample Collection. At each selected sampling date, pots were picked up randomly and sacrificed for collecting plant samples and soil samples. The plants were carefully removed from the pots, and the soil which was left in the pots was defined as bulk soil in which the influence of plant roots was negligible. ${ }^{13}$ The collected bulk soil was mixed thoroughly for further use. The soil that was loosely attached to the roots was first removed by shaking the plants (discarded), and then the soil that closely adhered to the roots was collected as the rhizosphere soil $(<1 \mathrm{~mm}$ away from the root) by following the method reported by Guan et 


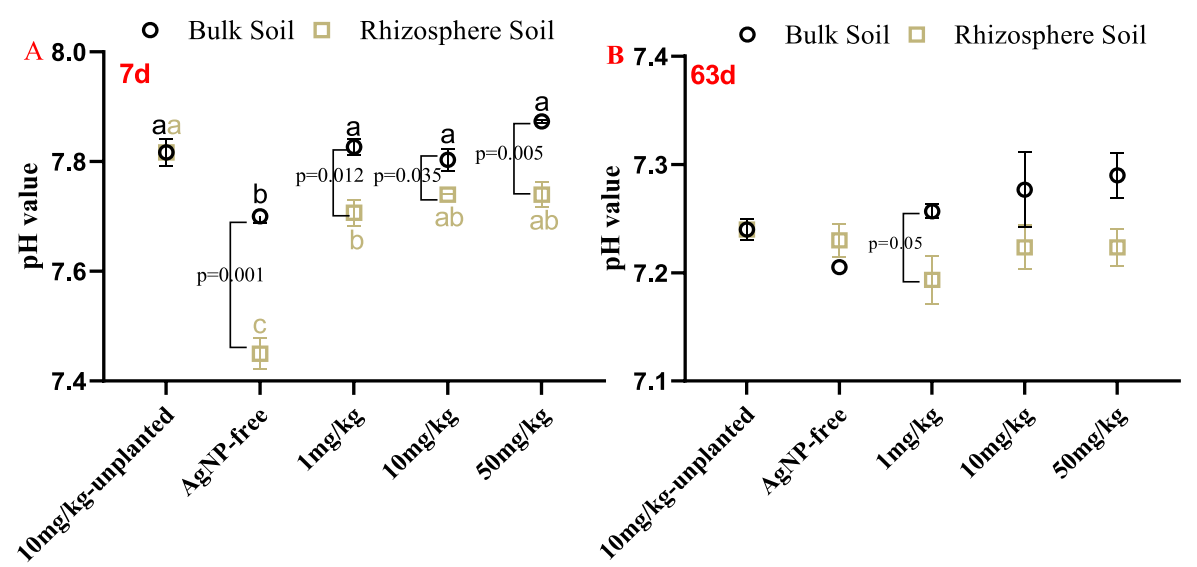

Figure 1. Soil $\mathrm{pH}$ in the rhizosphere soil and bulk soil exposed to AgNPs with or without plants for $7 \mathrm{~d}$ (A) and $63 \mathrm{~d}$ (B). Different letters indicate the significant difference among the treatments of the same soil $(p<0.05)$. The numbers indicate the significant differences between the bulk soil and rhizosphere soil under the same treatment $(p<0.05)$. Data are expressed as mean \pm scanning electron microscopy (SEM) of triplicate samples.

al. ${ }^{17}$ The collected rhizosphere soil was mixed thoroughly for further use. For $\mathrm{Ag}$ extraction and $\mathrm{pH}$ measurement, the bulk soil and rhizosphere soil samples were air-dried. The rhizosphere soil samples used for the soil DNA extraction were stored at $4{ }^{\circ} \mathrm{C}$.

After collecting the soil samples, the plants were thoroughly washed with flowing tap water and rinsed in deionized water for $10 \mathrm{~min}$, which was repeated 3 times. Subsequently, the plants were divided into root and shoot and after air drying, and the biomass of plant roots and shoots was recorded. To determine the Ag content in the plants, the plants were first washed with $10 \mathrm{mM} \mathrm{HNO}_{3}, 10 \mathrm{mM}$ EDTA, and Milli-Q water to remove the attached $\mathrm{AgNPs} / \mathrm{Ag}^{+}$ions, as described previously. ${ }^{11}$ Next, the plants were oven-dried, weighed, and digested with $\mathrm{HNO}_{3}(65 \%)$ and $\mathrm{H}_{2} \mathrm{O}_{2}(30 \%)$ at $120{ }^{\circ} \mathrm{C}$. ${ }^{11}$ Finally, the digests were diluted, and $\mathrm{Ag}$ concentrations were analyzed by means of graphite furnace atomic absorption spectrometry (AAS, PerkinElmer $1100 \mathrm{~B}$, Waltham, MA, USA). The bioaccumulation factor (BAF) of $\mathrm{Ag}$ from soil to plant roots and the translocation factor (TF) of Ag from roots to shoots were calculated as follows ${ }^{11}$

$$
\begin{gathered}
\mathrm{BAF}=\frac{[\mathrm{Ag}]_{\text {root }}}{[\mathrm{Ag}]_{\text {soil }}} \\
\mathrm{TF}=\frac{[\mathrm{Ag}]_{\text {shoots }}}{[\mathrm{Ag}]_{\text {roots }}}
\end{gathered}
$$

where $[\mathrm{Ag}]_{\text {root }}$ represents the concentrations of $\mathrm{Ag}$ in the plants $(\mathrm{mg} /$ $\mathrm{kg}),[\mathrm{Ag}]_{\text {soil }}$ represents the exposure concentration of AgNPs in the soil $(\mathrm{mg} / \mathrm{kg})$, and $[\mathrm{Ag}]_{\text {shoots }}$ represents the $\mathrm{Ag}$ concentration in plant shoot tissues $(\mathrm{mg} / \mathrm{kg})$.

Labile Ag Extraction from AgNP-Amended Soil and Soil pH Measurement. On each sampling day, $\sim 2.0 \mathrm{~g}$ of air-dried soil samples was extracted with $20 \mathrm{~mL}$ of the $\mathrm{CaCl}_{2}$ extractant or $4 \mathrm{~mL}$ of the DTPA extractant. ${ }^{13} \mathrm{CaCl}_{2}$ can extract the metals from the soil by making use of cation competition processes, which has been considered to be "readily available" to plants/soil organisms. DTPA extraction is used for extracting the "readily available" fraction and the "potentially available" fraction that is reversibly bound to the soil solid matrix, which has been suggested to be an indication for metallic NP dissolution in soil. ${ }^{13}$ The $\mathrm{CaCl}_{2}$ extractant was prepared by dissolving the $\mathrm{CaCl}_{2}$ salt in Milli- $\mathrm{Q}$ water to reach a final concentration of 0.01 M. The DTPA extractant was a mixture of $0.005 \mathrm{M}$ DTPA, $0.01 \mathrm{M}$ $\mathrm{CaCl}_{2}$, and $0.1 \mathrm{M}$ triethanolamine. All extractions were conducted using a reciprocal shaker for $2 \mathrm{~h}$ at $180 \mathrm{rpm}$. After extraction, the samples were centrifuged at $4500 \mathrm{rpm}$ for $30 \mathrm{~min}$ and the supernatants were filtered using a $0.22 \mu \mathrm{m}$ filter. Afterward, the filter samples were acidified with concentrated $\mathrm{HNO}_{3}$ (the final $\mathrm{HNO}_{3}$ concentrations were less than $2 \%$ ) and stored at $4{ }^{\circ} \mathrm{C}$ before performing inductively coupled plasma-mass spectrometry (ICPMS) measurements. Standard Ag solutions of $0.5 \mathrm{mg} / \mathrm{L}$ (AAS) and 10 $\mathrm{ng} / \mathrm{L}$ (for ICP-MS) were measured for every 20 samples to monitor the stability of the machines. Blanks and $\mathrm{Ag}$ standard solutions were included in the digestion procedure for the purposes of quality control. The average recovery of $\mathrm{Ag}$ for the digestion procedure was $91 \%$ with the standard deviation of $7 \%$, and the recovery for the machines was between 99 and $101 \%$. The detection limits for AAS and ICP-MS were $1 \mu \mathrm{g} / \mathrm{L}$ and $1 \mathrm{ng} / \mathrm{L}$, respectively. The RSDs for all sample measurements were below $5 \%$.

Within all sample treatments and times, the $\mathrm{pH}$ of the original supernatants (without centrifugation, filter, and acidification) was measured from the $\mathrm{CaCl}_{2}$ extracts representing the soil $\mathrm{pH}$ of the soilextractable available fraction. ${ }^{19}$

Rhizosphere Soil DNA Extraction and Illumina Miseq Sequencing. The DNA from the soil rhizosphere was extracted using a Qiagen DNeasy PowerSoil kit (Hilden, Germany). After quality control checking, a universal bacterial primer set $\left(515 \mathrm{~F}\right.$ : $5^{\prime}$ G T GCCAGCMGCCGCGGTAA - $3^{\prime}$ and 909R: 5' CCCGTCAATTCMTTTRAGT-3') was used for PCR amplification by targeting the variable V4-V5 regions of bacterial $16 \mathrm{~S}$ rRNA genes. Paired-end sequencing was done using a $2 \times 300 \mathrm{bp}$ Illumina Miseq platform (Illumina, Inc., San Diego, CA, USA) by BaseClear (Leiden, The Netherlands). The obtained sequences have been deposited into the National Center for Biotechnology Information (NCBI) database (project number: PRJNA732000). The quantitative insights into microbial ecology (QIIME2) pipeline was used to process the sequences. Sequence quality control was performed using the software package DADA2. Qualifying sequences were processed to construct the FeatureTable that was collapsed at the genus level (i.e., level 6 of the Greengenes taxonomy). The q2-phylogeny plugin was used to build the phylogenetic tree (Figure S2), and the q2-diversity plugin was used to compute alpha and beta diversity metrics. The sampling depth was rarefied to remove the heterogeneity (Figure S3). The q2feature-classifier plugin was used for taxonomic assignment.

Statistical Analysis. Statistically significant differences regarding the $\mathrm{CaCl}_{2}$-extractable $\mathrm{Ag}$, DTPA-extractable $\mathrm{Ag}$, plant biomass, and $\mathrm{Ag}$ content in plants in treatment were analyzed by means of one-way ANOVA, followed by Duncan's honestly significant difference tests at $\alpha<0.05$ using IBM SPSS Statistics 25 (no deviations in the data were found for normal distribution and homogeneity of variance with the Shapiro-Wilk test and Bartlett test prior to the ANOVA test). The $t$ test was performed to determine the differences of the tested end points between bulk soil and rhizosphere soil $(\alpha<0.05)$. The results are expressed as mean \pm standard error of three replicates. The QIIME2 diversity alpha-group-significance plugin was used to test the significance of the Shannon index across the different treatments. The principal coordinates analysis ( $\mathrm{PCoA}$ ) based on the weighted UniFrac distance matrices was applied to compare community dissimilarities, and permutational multivariate analysis of variance (PERMANOVA) was used for the significance test. The featured taxa that are 

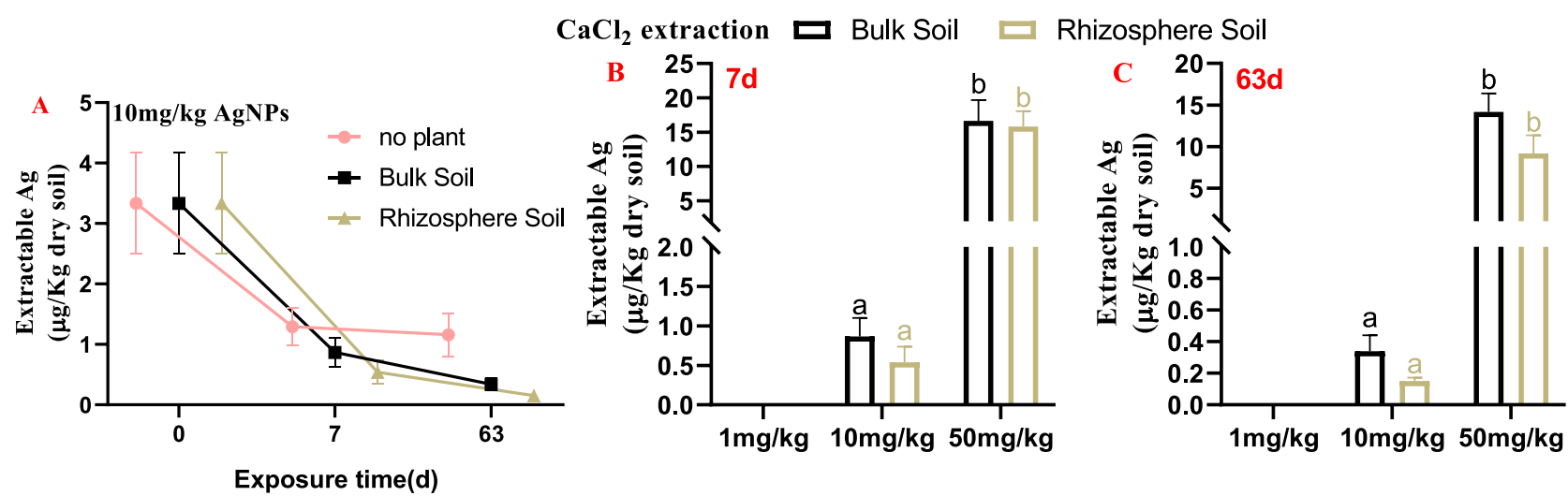

Exposure time(d)
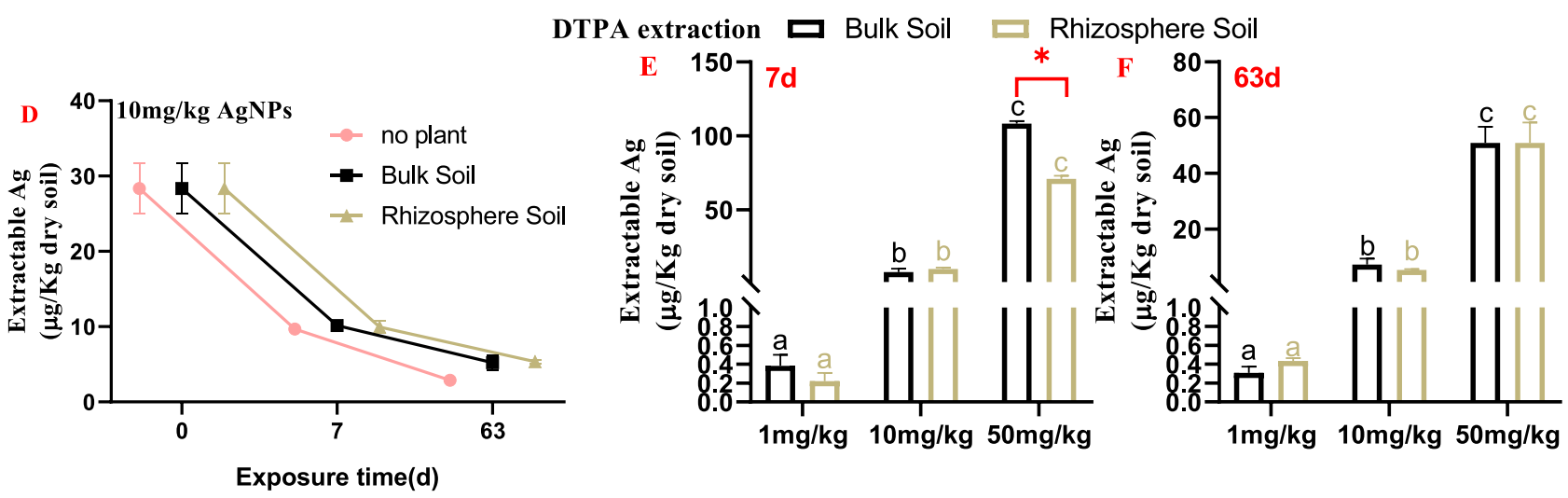

Figure 2. $\mathrm{CaCl}_{2}$ - and DTPA-extractable Ag in AgNP-amended soil. (A,D) Changes in the response to the presence of plants for $10 \mathrm{mg} / \mathrm{kg}$ AgNP treatment over time. (B,E) Changes in the bulk and rhizosphere soil with different concentrations of AgNPs after $7 \mathrm{~d}$ of exposure. (C,F) Changes in the bulk and rhizosphere soil with different concentrations of AgNPs after $63 \mathrm{~d}$ of exposure. Different letters indicate statistically significant differences among the treatments in the same soil $(p<0.05)$. The * indicates the significant differences between the bulk soil and the rhizosphere soil under the same treatment $(p<0.05)$. Data are expressed as mean \pm SEM of triplicate samples.

differentially abundant in each treatment were identified using analysis of composition of microbiomes (ANCOM). The false discovery rate test was used to correct the $p$-values from false positives in the multicomparison tests. Spearman correlations between the tested end points were analyzed in $\mathrm{R}$ with the package of "ggcorrplot" and were considered significant when $p<0.05$.

\section{RESULTS}

Soil pH Changes in Bulk and Rhizosphere Soil after Amendment. The results showed that the addition of AgNPs significantly increased the soil $\mathrm{pH}$ of both unplanted (from 7.70 to 7.82 ) and planted soil (from 7.70 to 7.87 ) after $7 \mathrm{~d}$ of incubation (Figure 1A). However, the significant differences between the control treatment and AgNP treatments disappeared after long-term exposure $(63 \mathrm{~d})$. Additionally, the soil $\mathrm{pH}$ of all treatments decreased after long-term exposure as compared to short-term exposure $(7 \mathrm{~d})$. Noteworthily, no significant difference in the soil $\mathrm{pH}$ was observed between $10 \mathrm{mg} / \mathrm{kg}$ AgNP planted and unplanted soil regardless of the exposure duration $(p=0.184$ for $7 \mathrm{~d}$ and $p=$ 0.956 for $63 \mathrm{~d}$ ). In addition, the soil $\mathrm{pH}$ did not differ between the treatments amended with different concentrations of AgNPs regardless of the exposure duration (Figure 1).

Changes in Extractability of $\mathrm{Ag}$ in the Bulk and Rhizosphere Soil. For the freshly prepared $1 \mathrm{mg} / \mathrm{kg}$ AgNPamended soil (day 0 refers to the transplantation date), the $\mathrm{CaCl}_{2}$-extractable amounts of $\mathrm{Ag}$ were below the detection limit, while the corresponding DTPA-extractable amount of Ag was $7 \pm 2 \mu \mathrm{g} / \mathrm{kg}$. Similarly, the $\mathrm{CaCl}_{2}$-extractable amounts of
Ag were $3.3 \pm 0.8$ and $29 \pm 5 \mu \mathrm{g} / \mathrm{kg}$ for the 10 and $50 \mathrm{mg} / \mathrm{kg}$ AgNP-amended soils, while the DTPA-extractable amounts of Ag were $28 \pm 3$ and $142 \pm 4 \mu \mathrm{g} / \mathrm{kg}$ for the 10 and $50 \mathrm{mg} / \mathrm{kg}$ AgNP-amended soils, respectively. Upon increasing the incubation time, the extractable amount of $\mathrm{Ag}$ in both unplanted and planted soils decreased (Figure 2A). For example, for the $10 \mathrm{mg} / \mathrm{kg}$ AgNP unplanted soil, the DTPAextractable amount of $\mathrm{Ag}$ decreased from $28 \pm 3$ to $9.7 \pm 0.5$ $\mu \mathrm{g} / \mathrm{kg}$ (incubation for $7 \mathrm{~d}$ ) to $2.9 \pm 0.1 \mu \mathrm{g} / \mathrm{kg}$ (incubation for $63 \mathrm{~d})$. Regarding the extractability of $\mathrm{Ag}$ in unplanted and planted soils for the same cultivation time, the DTPAextractable amount of $\mathrm{Ag}$ in the bulk soil and rhizosphere soil was similar to $7 \mathrm{~d}$ or significantly higher than $63 \mathrm{~d}$ (ANOVA, $p=0.01$ ) unplanted soil, while the $\mathrm{CaCl}_{2}$ extractable amount of $\mathrm{Ag}$ in both cultivation time followed the order unplanted soil $>$ bulk soil $>$ rhizosphere soil.

The differences in $\mathrm{CaCl}_{2}$-extractable $\mathrm{Ag}$ and DTPAextractable $\mathrm{Ag}$ for the AgNP-amended soil with different concentrations of AgNPs in the bulk soil and rhizosphere soil are shown in Figure 2. A clear concentration-dependent impact on the extractable amount of $\mathrm{Ag}$ was observed for both bulk soil and rhizosphere soil regardless of the $\mathrm{CaCl}_{2}$ extractant or DTPA extractant. For the low AgNP concentration $(1 \mathrm{mg} / \mathrm{kg})$, the amount of $\mathrm{Ag}$ extracted by $\mathrm{CaCl}_{2}$ extraction was below the detection limit, while the DTPA-extractable amount of Ag was less than $0.5 \mu \mathrm{g} / \mathrm{kg}$ soil. Compared to the concentration of the $10 \mathrm{mg} / \mathrm{kg}$ AgNP-amended soil, the extractable amount of Ag in the soil amended with $50 \mathrm{mg} / \mathrm{kg}$ AgNPs was significantly 

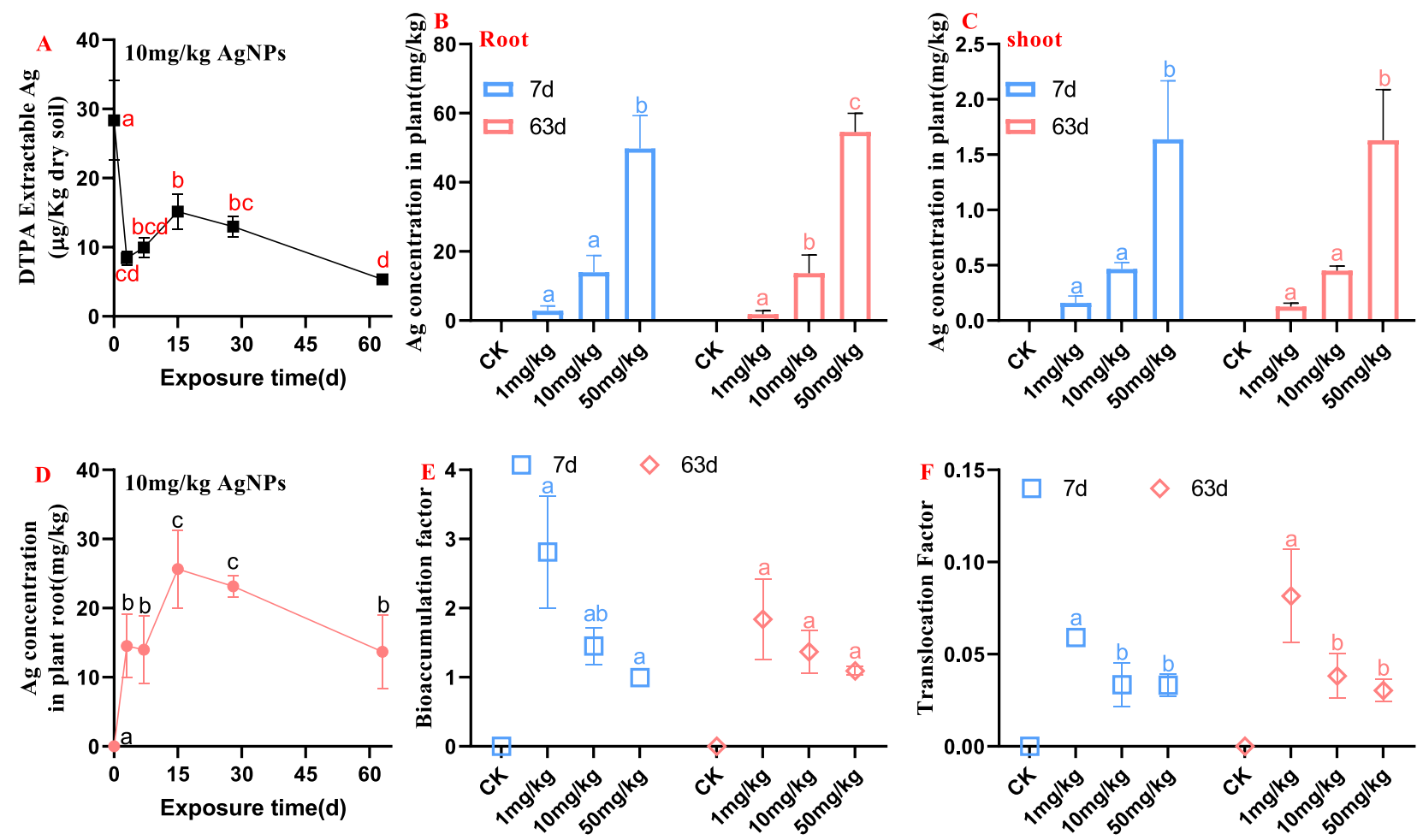

Figure 3. DTPA-extractable $\mathrm{Ag}$ in rhizosphere soil (A) and $\mathrm{Ag}$ accumulation in plant roots (D) in $10 \mathrm{mg} / \mathrm{kg}$ AgNP treatment over time. Ag accumulation in the plant root (B), plant shoot (C), and the BAFs (E) and TFs (F) at different AgNP concentrations after 7 and $63 \mathrm{~d}$ of exposure. The concentrations of Ag in plant roots and shoots for the control treatment were considered as 0 as they were below the detection limit. Different letters indicate a statistically significant difference among the treatments with the same exposure duration $(p<0.05)$. Data are expressed as mean \pm SEM of triplicate samples. CK means the control treatment.

increased by a factor of $19-61$ for $\mathrm{CaCl}_{2}$ extraction and 7-14 for DTPA extraction under different conditions. Between the bulk soil and rhizosphere soil, no significant differences were observed for the $\mathrm{CaCl}_{2}$-extractable $\mathrm{Ag}$ regardless of the exposure concentration or time. For DTPA-extractable Ag, significant differences between the bulk and rhizosphere soil were only observed for the soil to which $50 \mathrm{mg} / \mathrm{kg}$ AgNPs were added ( $t$-test, $p<0.005)$.

We also investigated the changes in the extractability of AgNPs in the rhizosphere soil ( $10 \mathrm{mg} / \mathrm{kg}$ AgNPs) over time by DTPA extraction, as shown in Figure 3A. An interesting tendency was observed as the DTPA-extractable $\mathrm{Ag}$ in the rhizosphere soil decreased rapidly in the first $3 \mathrm{~d}$ of cultivation and then increased gradually after 7 and $15 \mathrm{~d}$ of cultivation but decreased again from 15 to $63 \mathrm{~d}$ of cultivation. In addition, the extractable amount of $\mathrm{Ag}$ in the planted soil after $7 \mathrm{~d}$ of cultivation was slightly higher when compared to the extractable amount of $\mathrm{Ag}$ after $63 \mathrm{~d}$ of cultivation in all experimental scenarios. However, statistically significant differences were only observed in $50 \mathrm{mg} / \mathrm{kg}$ AgNP-amended bulk soil for DTPA extraction ( $p<0.005$, $t$-test).

Ag Accumulation and Translocation in the Soil-Plant System. During the same exposure duration (7 or $63 \mathrm{~d}$ ), no significant differences in the plant biomass were observed between the control treatment and AgNP treatments regardless of the exposure concentration $(p=0.858$ for $7 \mathrm{~d}$ and $p=0.541$ for $63 \mathrm{~d}$, Figure S4).

The change in the $\mathrm{Ag}$ concentration in plant roots in $10 \mathrm{mg} /$ $\mathrm{kg}$ AgNP treatment over time is shown in Figure 3D. The Ag concentrations in the plant roots increased after 3,7 , and $15 \mathrm{~d}$ of cultivation and then decreased during the cultivation period of 15-63 d, which followed the same pattern of the DTPAextractable $\mathrm{Ag}$ in the corresponding rhizosphere soil over time. Interestingly, when comparing the Ag concentrations in plants upon $7 \mathrm{~d}$ cultivation to $63 \mathrm{~d}$ cultivation at the same applied AgNPs dose, no significant difference was observed (Figure 3B, $t$-test, $p>0.05$ ).

Figure 3 also shows the accumulation and translocation of $\mathrm{Ag}$ in the plant tissues after cultivation for 7 and $63 \mathrm{~d}$ in soil to which different amounts of AgNPs were added. The $\mathrm{Ag}$ concentrations in the plant roots were more than 10 times higher than the Ag concentration in the corresponding shoots upon exposure to the same concentration and time. Moreover, $\mathrm{Ag}$ was taken up by plant roots and translocated into plant shoots in all AgNP-amended treatments with a general concentration-dependent increase. For example, the $\mathrm{Ag}$ concentrations in lettuce shoots were around $1.6 \mathrm{mg} \mathrm{Ag} / \mathrm{kg}$ plant for the treatment of $50 \mathrm{mg} / \mathrm{kg}$ AgNPs, which is $10-13$ times higher than that found in the shoots of plants exposed to $1 \mathrm{mg} / \mathrm{kg} \mathrm{AgNP}$-amended soils $(0.16 \mathrm{mg} / \mathrm{kg}$ for $7 \mathrm{~d}$ and 0.13 $\mathrm{mg} / \mathrm{kg}$ for $63 \mathrm{~d}$ ).

In addition, the BAFs of $\mathrm{Ag}$ in all exposure treatments were higher than 1. The high Ag concentrations in plant roots and the high BAFs of $\mathrm{Ag}$ indicated the potential biomagnification of $\mathrm{Ag}$ from soil to the plant. The presence of $\mathrm{Ag}$ in plant shoots shows the translocation ability of $\mathrm{Ag}$ from plant roots to shoots, even though the TFs of $\mathrm{Ag}$ in all treatments were lower than 0.1 .

Response of Soil Microbial Communities to AgNPs in the Rhizosphere Soil. The alterations of the bacterial community in the rhizosphere in response to AgNP exposure was further investigated. The Shannon index, which reflects the 

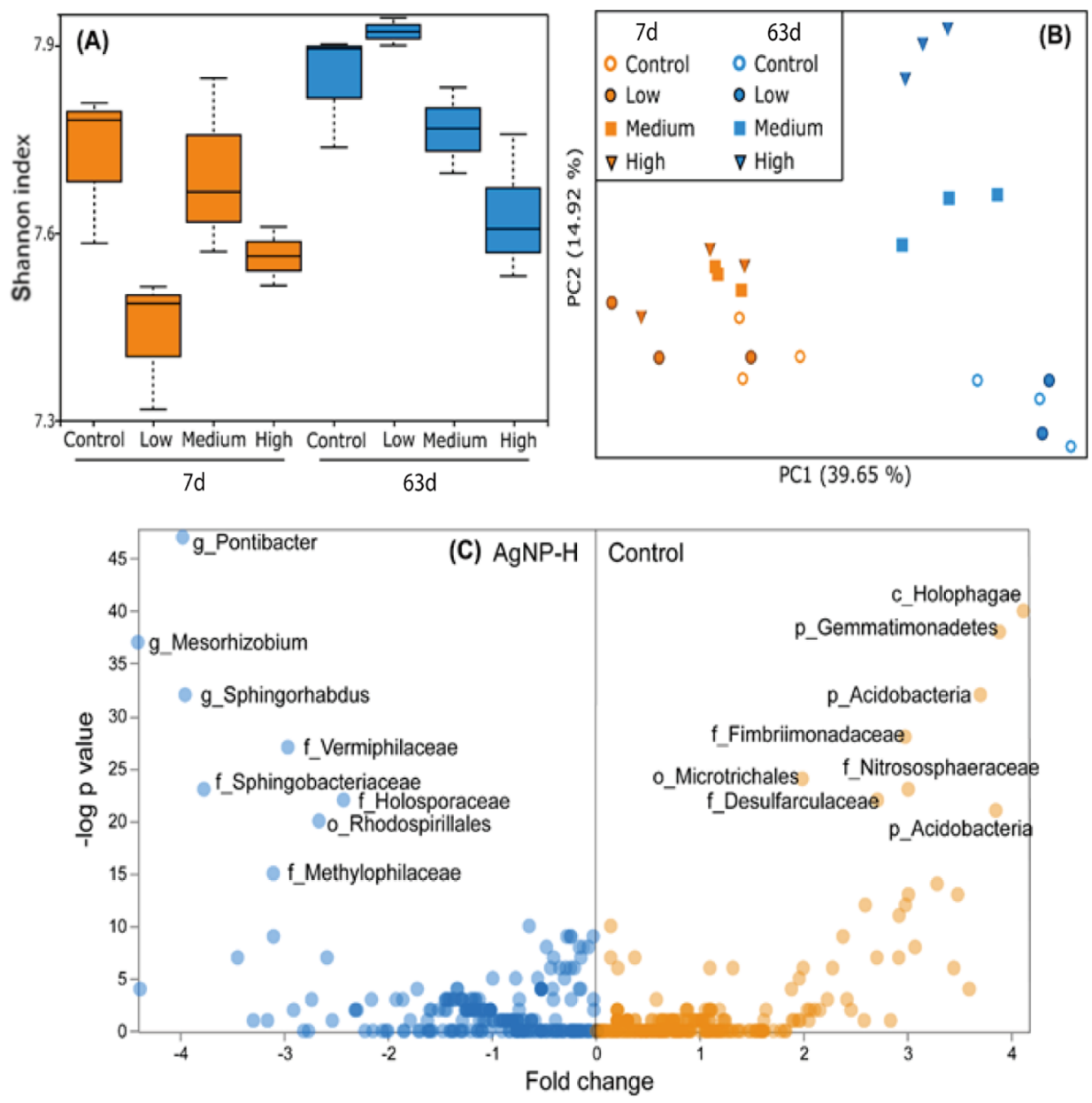

Figure 4. (A) Changes in the community $(\alpha)$ diversity shown as the Shannon index. (B) PCoA of the bacterial community structure. (C) Featured taxa identified between the control and soil amended with $50 \mathrm{mg} / \mathrm{kg}$ AgNPs upon $63 \mathrm{~d}$ of incubation.

species richness, was used to evaluate the alpha diversities of the rhizosphere bacteria in the control soil and in AgNPamended soil. During $7 \mathrm{~d}$ of incubation, the changes in the Shannon indices among the control and the soil amended with different concentrations of AgNPs were irregular. However, after increasing the incubation duration to $63 \mathrm{~d}$, a clear tendency was observed and the Shannon index decreased upon exposure to increasing concentration of AgNPs.

The shifts in the rhizosphere bacterial community structure induced by AgNP treatments over time were further analyzed by PCoA (Figure 4B). After incubation for $7 \mathrm{~d}$, the bacterial communities in the control and different AgNP treatment samples clustered together. However, when the incubation time was increased to $63 \mathrm{~d}$, the bacterial communities exposed to $10 \mathrm{mg} / \mathrm{kg}$ AgNPs and $50 \mathrm{mg} / \mathrm{kg}$ AgNPs were clearly separated from the control. Moreover, the bacterial communities in 10 and $50 \mathrm{mg} / \mathrm{kg}$ AgNP-amended soils separated from each other. This indicates that the impacts of AgNPs on the bacterial community structure are time-dependent.

Additionally, the community composition at the phylum level in response to different treatments is provided in Figure S5. Proteobacteria (with an average relative abundance of 29$34 \%)$, Actinobacteria (27-31\%), Bacteroidetes (9-14\%), and Acidobacteria $(9-11 \%)$ were the dominant bacterial phyla in both the control soil and AgNP-amended soil after $7 \mathrm{~d}$ of incubation. By increasing the incubation period from 7 to $63 \mathrm{~d}$, the average relative abundance of Actinobacteria decreased from $27-31$ to $16-20 \%$, again indicating that the effect of AgNPs on the bacterial composition is time-dependent. The featured taxa that are differentially abundant in the different treatment samples were identified using ANCOM analysis (Figure 4C). In general, no featured taxa were found in the AgNP treatment samples after $7 \mathrm{~d}$ of incubation. After incubation for $63 \mathrm{~d}$, a total of 16 featured taxa were observed, which greatly contributed to the observed differences between the $50 \mathrm{mg} / \mathrm{kg} \mathrm{Ag-amended} \mathrm{soil} \mathrm{and} \mathrm{the} \mathrm{control} \mathrm{soil.} \mathrm{From}$ these featured taxa, eight taxa (including the phyla Acidobacteria and Gemmatimonadetes, the class Holophagae, the order Microtrichales, the families Fimbriimonadaceae, Nitrososphaeraceae, and Desulfarculaceae) were downregulated and eight taxa (including the order Rhodospirillales, the families Vermiphilaceae, Sphingobacteriaceae, Holosporaceae, and Methylophilaceae, and the genera Pontibacter, Mesorhizobium, and Sphingorhabdus) were upregulated in $50 \mathrm{mg} / \mathrm{kg}$ AgNPs when compared with the control. These results further confirmed a long-term impact of a high concentration of AgNPs on the rhizosphere bacterial community composition.

Correlation Analysis of Exposure Conditions, Soil pH, Extractable Ag in Soil, Plant Parameters, and Soil Bacterial Communities. As shown in the map of Spearman's correlations (Figure 5), the soil $\mathrm{pH}$ was negatively correlated with the exposure time but had no significant relationship with the exposure concentration. The amount of DTPA-extracted $\mathrm{Ag}$ in both bulk and rhizosphere soil was significantly and 


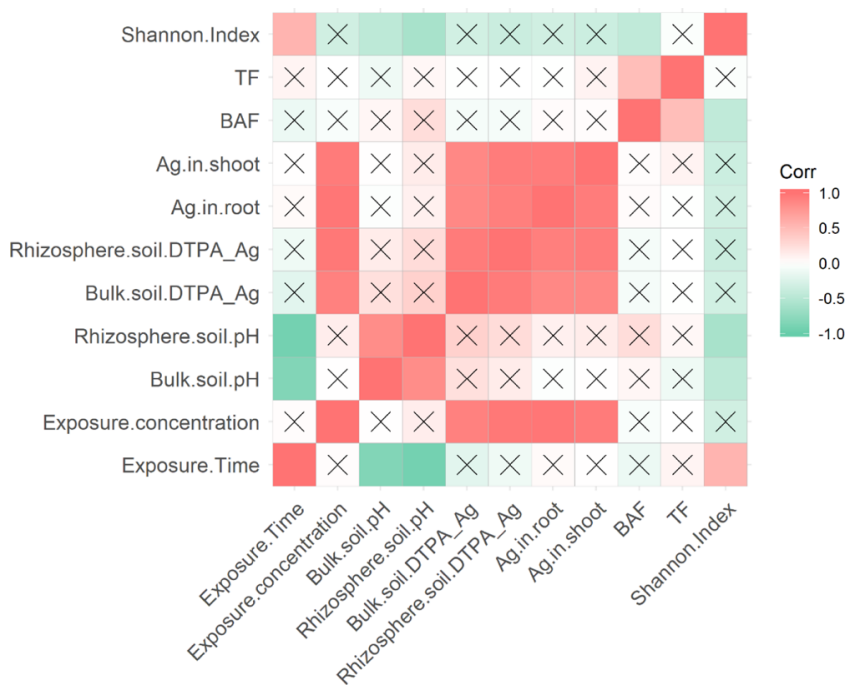

Figure 5. Spearman correlation map between the tested parameters including the exposure conditions, soil $\mathrm{pH}$, extractable $\mathrm{Ag}$ in soil, plant-related parameters, and Shannon index of the soil bacterial community. Correlations with $p>0.05$ fill with $\times$. Significant negative correlations (corr $<0)$ are given in gradations of green. Positive correlations (corr $>0)$ are given in gradations of red.

positively correlated with the exposure concentration of AgNPs since all correlation coefficients were higher than 0.9. In addition, the amount of $\mathrm{Ag}$ accumulated in the plant root and the shoots was correlated positively with DTPA-extracted Ag in the soil. Root and shoot concentrations were highly related because of the translocation of $\mathrm{Ag}$ after uptake via the roots. No relationships were observed between the exposure time or soil $\mathrm{pH}$ and extractable $\mathrm{Ag}$ in soil, as well as the $\mathrm{Ag}$ content in plants. On the contrary, the Shannon index of the soil bacterial community positively correlated with the exposure time but negatively correlated with the soil $\mathrm{pH}$ and the BAFs of $\mathrm{Ag}$ in plants.

\section{DISCUSSION}

Overall, this study enhanced the understanding of how the dynamic dissolution of AgNPs in soil affect their bioavailability in the rhizosphere-lettuce interface and of long-term impacts of AgNPs on the rhizosphere soil bacterial community. Our results revealed that the addition of AgNPs significantly increased the soil $\mathrm{pH}$ after $7 \mathrm{~d}$ of incubation regardless of the presence of lettuce plants (Figure 1A). This statistically significant increase is in line with the results of previous studies reporting an increase of the soil $\mathrm{pH}$ after amending soil with metallic NPs. ${ }^{14,32}$ The alterations of the soil metabolite profiles and the abundance and composition of root exudates can change the soil $\mathrm{pH}^{13,14}$ For example, Zhang et al. ${ }^{14}$ suggested that the increase of the soil $\mathrm{pH}$ might be attributed to the decrease of the concentrations of several fatty acids in metabolites of the soil induced by exposure to AgNPs. Additionally, the dissolution of AgNPs can also contribute to higher $\mathrm{pH}^{19}$ as it can consume the $\mathrm{H}^{+}$in the system or release $\mathrm{OH}^{-}$into soil following the stoichiometry below ${ }^{33}$

$$
2 \mathrm{Ag}(\mathrm{s})+1 / 2 \mathrm{O}_{2}+2 \mathrm{H}^{+} \rightarrow 2 \mathrm{Ag}^{+}+2 \mathrm{H}_{2} \mathrm{O}
$$

or $^{34}$
$\mathrm{Ag}_{2} \mathrm{O}$ (oxide layer formed on the surface of AgNPs)

$$
+\mathrm{H}_{2} \mathrm{O} \rightarrow 2 \mathrm{Ag}^{+}+2 \mathrm{OH}^{-}
$$

However, the soil $\mathrm{pH}$ decreased after increasing the incubation time to $63 \mathrm{~d}$ and no significant differences were observed between treatments after $63 \mathrm{~d}$ of incubation. This pattern was similar to the findings of Das et al., ${ }^{35}$ who also reported that the soil $\mathrm{pH}$ increased during the initial exposure period but decreased after the long-term exposure. The findings suggest that the aging of AgNPs in the soil neutralized the $\mathrm{pH}$ changes between treatments.

The dissolution of metallic NPs is known to be the dominant process governing the availability of metals derived from metallic NPs. ${ }^{19}$ Thus, the dissolution of AgNPs in soil over time was investigated using DTPA extraction. The DTPAextractable $\mathrm{Ag}$ was less than $0.3 \%$ for all experimental scenarios, suggesting that the dissolution of AgNPs in soil was very limited, even in the rhizosphere. This was in line with previous studies, ${ }^{18,36}$ which also revealed the very low lability/ release of Ag from AgNP-amended soil. Interestingly, a gradual increase of DTPA-extractable $\mathrm{Ag}$ in the rhizosphere soil was observed during the cultivation period from 3 to $15 \mathrm{~d}$ (Figure $3 \mathrm{~A}$ ), indicating the gradual dissolution of AgNPs in the soil. However, the extractable $\mathrm{Ag}$ in the rhizosphere soil decreased as the cultivation period increased from 15 to $63 \mathrm{~d}$. Also, the $\mathrm{Ag}$ concentration extracted from the AgNP-amended soil after $63 \mathrm{~d}$ of cultivation was slightly lower than the $\mathrm{Ag}$ concentration after $3 \mathrm{~d}$ and $7 \mathrm{~d}$ of cultivation. There are several possible explanations for this observation of declining $\mathrm{Ag}$ concentrations. First, the dissolution of AgNPs might have become slower after $15 \mathrm{~d}$ of cultivation, or the AgNPs dissolution reached saturation over after longer exposure duration. There is a plethora of information revealing the two-phase dissolution behavior of AgNPs, containing a short but rapid initial release phase and a longer but slower second release phase. ${ }^{37,38}$ Second, the uptake of Ag by plant roots was much faster than the dissolution process of AgNPs in soil, as indicated by comparing the extractable $\mathrm{Ag}$ from AgNPs and the $\mathrm{Ag}$ uptake by plant roots over time (Figure $3 A, D)$. This led to a relative decrease of $\mathrm{Ag}$ accumulation in the plants for the cultivation period from 15 to $63 \mathrm{~d}$. Finally, this decline might be a result of the combination of $\mathrm{Ag}$ precipitation, irreversible binding of $\mathrm{Ag}^{+} / \mathrm{AgNPs}$ to the solid soil matrix, and the transformation of AgNPs in soil. ${ }^{10}$ After long-term exposure in soil, AgNPs have a large potential of being transformed to silver sulfide or other sulfur-bound $\mathrm{Ag}$ forms, ${ }^{18,39}$ which will reduce the solubility and extractability of AgNPs. A previous study also found that the concentration of labile $\mathrm{Ag}$ in soil was significantly decreased by increasing the incubation time to 2 weeks and to 6 months and evidenced that the $\mathrm{S}$ group-bound $\mathrm{Ag}$ was the predominant form after the soil was amended with soluble $\mathrm{Ag}^{40}$ the so-called aging processes. The changes in the extractable concentration of Ag over time suggest that a single or fixed exposure duration cannot capture the actual dissolution and accumulation process of AgNPs in soil, ${ }^{13}$ which may result in inaccurate assessment of the bioavailability or toxicity of AgNPs.

Our results demonstrated that the DTPA-extractable Ag concentration in unplanted soil, bulk soil, and rhizosphere soil was almost equal (Figure 2D), suggesting that the effect of lettuce on the dissolution of AgNPs was limited. The $\mathrm{CaCl}_{2}-$ extractable amount of $\mathrm{Ag}$ followed the order unplanted soil > 
bulk soil $>$ rhizosphere soil (Figure 2A). This indicates that $\mathrm{CaCl}_{2}$-extractable $\mathrm{Ag}$ is a better predictor of $\mathrm{Ag}$ uptake by plants as it better represents the more "readily available" Ag form. Gao et al. ${ }^{13}$ also suggested that DTPA extraction is a better indication for metallic NP dissolution in soil, while $\mathrm{CaCl}_{2}$ extraction provides a more accurate prediction of the uptake of NPs by plants. The observed Ag in plant shoot tissues shows the translocation of $\mathrm{Ag}$ from roots to shoots. In addition, the $\mathrm{Ag}$ accumulation and translocation positively correlated with the extractable amount of Ag in soil (Figure 5), and the trend of $\mathrm{Ag}$ accumulation in the plants over time was similar to the dissolution of AgNPs in soil (Figure 3). These results indicate that the dissolution of AgNPs is the predominant process related to the Ag uptake by plant roots.

For the rhizosphere bacterial community, we did not observe any significant impact of AgNPs during a short-term exposure $\left(\begin{array}{ll}7 & \mathrm{~d}\end{array}\right)$ regardless of the exposure concentration. However, after long-term exposure (63 d), the Shannon index decreased, and the bacterial communities separated from the control with increasing exposure concentration. This suggests that the effects of AgNP concentration on the diversity and composition of the rhizosphere bacterial community varied over time. Moreover, eight upregulated bacterial taxa and eight downregulated featured taxa were only observed in the treatment with $50 \mathrm{mg} / \mathrm{kg}$ AgNPs after $63 \mathrm{~d}$ of exposure, which contributed the most in inducing the differences between AgNP treatment and the control. Previous research stated that the soil microbiome can shift its composition by increasing the Ag-tolerant taxa in response to AgNP stress. ${ }^{21,41}$ Similarly, the abundance of Ag-resistant and -sensitive genus Mesorhizobium $^{42}$ was found to be increased in the soil amended with high concentration of AgNPs in our study. In addition, several bacterial groups associated with the removal/ degradation of a number of contaminants were stimulated in response to AgNPs, including the genus Pontibacter that is able to remove metals ${ }^{42,43}$ and Sphingorhabdus and Sphingobacteriaceae that are related to the degradation of a variety of recalcitrant organic compounds. ${ }^{14,15,44}$ In addition, Pontibacter (strongly associated with the $\mathrm{N}$ fixation gene nifH), ${ }^{17}$ Mesorhizobium, ${ }^{39}$ and Rhodospirillales (containing free-living $\mathrm{N}_{2}$-fixing bacteria) $)^{15,41}$ were also promoted, indicating that the long-term exposure of AgNPs stimulates the bacterial taxa related to nitrogen cycling. Besides these upregulated bacterial taxa, several bacteria such as Acidobacteria and Desulfarculaceae were significantly inhibited upon long-term exposure to high concentrations of AgNPs. ${ }^{14,45,46}$ These bacteria are involved in carbon usage, sulfur reduction, and iron reduction. The alterations of the identified featured taxa highlight the potential disruption of agricultural systems because of AgNP exposure by affecting the functional bacterial groups associated with nutrient acquisition, stress tolerance, and biogeochemical element cycling (such as $\mathrm{C}, \mathrm{N}$, and S). Follow-up research, to determine the relationship among the content of the elements in soil (such as $\mathrm{C}, \mathrm{N}, \mathrm{P}$, and S), the nutrients in plants (such as proteins and phospholipids), and the abundance of genes involved in the biogeochemical element cycling in the rhizosphere soil amended with NPs, would be very interesting and valuable for understanding the interaction of NPs-plants-soil bacteria. Furthermore, the changes in the diversity and structure of the rhizosphere soil bacterial community over time also emphasize the importance of investigating the dynamic impacts of NPs on the rhizosphere bacterial communities.

\section{CONCLUSIONS}

Overall, the presence of lettuce played a limited role in affecting AgNP dissolution in soil as the extractability of $\mathrm{Ag}$ in unplanted and planted soil was similar under the same exposure conditions. We found that the dissolution of $\mathrm{AgNPs}$ in soil is the dominant process influencing $\mathrm{Ag}$ uptake via the roots and translocation to the shoots. The $\mathrm{Ag}$ extractability from AgNP-amended soil and accumulation of $\mathrm{Ag}$ in the plants changed over time. The diversity and composition of the rhizosphere soil bacterial community were altered after long-term exposure to high concentrations of AgNPs. These results highlight the importance of taking timeresolved dynamics of the soil-plant system in consideration in response to NP exposure. The slow but continuous dissolution of AgNPs in soil can provide a sustained antimicrobial effect against plant pathogens (phytopathogenic fungi, bacteria, and viruses). This implies that repetitive applications of AgNPs are not needed, which likely diminishes the total $\mathrm{Ag}$ concentration applied. This is an important potential benefit of using AgNPs containing agrochemicals compared to applying ionic $\mathrm{Ag}$ solutions. However, attention should still be paid to control the potential negative effects of AgNPs in soil-plant systems as high amounts of $\mathrm{Ag}$ in plant roots and the long-term alterations of the composition of the rhizosphere bacterial community were observed.

\section{ASSOCIATED CONTENT}

\section{(s) Supporting Information}

The Supporting Information is available free of charge at https://pubs.acs.org/doi/10.1021/acssuschemeng.1c04987.

TEM pictures of AgNPs, phylogenetic tree of the rhizosphere bacterial community, rarefaction curves of the rhizosphere bacterial communities, biomass of lettuce exposed to different treatments and the composition of the rhizosphere soil bacterial communities at the phylum/class levels, Hoagland's solution composition, hydrodynamic diameter and zeta potential of AgNP suspensions, and physicochemical properties of the soil and experimental design (PDF)

\section{AUTHOR INFORMATION}

\section{Corresponding Author}

Yujia Zhai - Institute of Environmental Sciences (CML), Leiden University, 2300 RA Leiden, The Netherlands; ๑ orcid.org/0000-0002-7412-6111; Email: y.zhai@ tudelft.nl

\section{Authors}

Juan Wu - Institute of Environmental Sciences (CML), Leiden University, 2300 RA Leiden, The Netherlands; ๑ orcid.org/ 0000-0003-2694-1127

Gang Liu - Key Laboratory of Drinking Water Science and Technology, Research Center for Eco-Environmental Sciences, Chinese Academy of Sciences, 100085 Beijing, China; Sanitary Engineering, Department of Water Management, Faculty of Civil Engineering and Geosciences, Delft University of Technology, 2600GA Delft, The Netherlands

Thijs Bosker - Institute of Environmental Sciences (CML), Leiden University, 2300 RA Leiden, The Netherlands; Leiden University College, Leiden University, 2501 EE The Hague, The Netherlands 
Martina G. Vijver - Institute of Environmental Sciences (CML), Leiden University, 2300 RA Leiden, The

Netherlands

Willie J. G. M. Peijnenburg - Institute of Environmental Sciences (CML), Leiden University, 2300 RA Leiden, The Netherlands; National Institute of Public Health and the Environment (RIVM), 3720 BA Bilthoven, The Netherlands

Complete contact information is available at:

https://pubs.acs.org/10.1021/acssuschemeng.1c04987

\section{Notes}

The authors declare no competing financial interest.

\section{ACKNOWLEDGMENTS}

The authors would like to thank Guiyin Wang (Leiden University) for the help with soil collection and preparation and Dr. Fazel Abdolahpur Monikh (Leiden University) for help with the ICP-MS measurements. The China Scholarship Council (CSC) is gratefully acknowledged for its financial support to J.W. (201706750014).

\section{REFERENCES}

(1) Singh, H.; Sharma, A.; Bhardwaj, S. K.; Arya, S. K.; Bhardwaj, N.; Khatri, M. Recent Advances in the Applications of Nano-Agrochemicals for Sustainable Agricultural Development. Environ. Sci.: Processes Impacts 2021, 23, 213-239.

(2) Lowry, G. V.; Avellan, A.; Gilbertson, L. M. Opportunities and Challenges for Nanotechnology in the Agri-Tech Revolution. Nat. Nanotechnol. 2019, 14, 517-522.

(3) Usman, M.; Farooq, M.; Wakeel, A.; Nawaz, A.; Cheema, S. A.; Rehman, H. u.; Ashraf, I.; Sanaullah, M. Nanotechnology in Agriculture: Current Status, Challenges and Future Opportunities. Science of the Total Environment; Elsevier B.V., 2020; p 137778.

(4) Silver Nanoparticles Market SizelGlobal Industry Report, 2012$2022 ; 2015$

(5) Rui, M.; Ma, C.; Tang, X.; Yang, J.; Jiang, F.; Pan, Y.; Xiang, Z.; Hao, Y.; Rui, Y.; Cao, W.; et al. Phytotoxicity of Silver Nanoparticles to Peanut (Arachis Hypogaea L.): Physiological Responses and Food Safety. ACS Sustain. Chem. Eng. 2017, 5, 6557-6567.

(6) Pu, S.; Yan, C.; Huang, H.; Liu, S.; Deng, D. Toxicity of Nano$\mathrm{CuO}$ Particles to Maize and Microbial Community Largely Depends on Its Bioavailable Fractions. Environ. Pollut. 2019, 255, 113248.

(7) Das, P.; Gogoi, N.; Sarkar, S.; Patil, S. A.; Hussain, N.; Barman, S.; Pratihar, S.; Bhattacharya, S. S. Nano-Based Soil Conditioners Eradicate Micronutrient Deficiency: Soil Physicochemical Properties and Plant Molecular Responses. Environ. Sci.: Nano 2021, 8, 2824.

(8) Gao, X.; Rodrigues, S. M.; Spielman-Sun, E.; Lopes, S.; Rodrigues, S.; Zhang, Y.; Avellan, A.; Duarte, R. M. B. O.; Duarte, A.; Casman, E. A.; et al. Effect of Soil Organic Matter, Soil PH, and Moisture Content on Solubility and Dissolution Rate of CuO NPs in Soil. Environ. Sci. Technol. 2019, 53, 4959-4967.

(9) Jośko, I.; Kusiak, M.; Oleszczuk, P. The Chronic Effects of $\mathrm{CuO}$ and $\mathrm{ZnO}$ Nanoparticles on Eisenia Fetida in Relation to the Bioavailability in Aged Soils. Chemosphere 2021, 266, 128982.

(10) Abbas, Q.; Yousaf, B.; Amina; Ali, M. U.; Munir, M. A. M.; ElNaggar, A.; Rinklebe, J.; Naushad, M. Transformation Pathways and Fate of Engineered Nanoparticles (ENPs) in Distinct Interactive Environmental Compartments: A Review. Environment International; Pergamon, 2020; p 105646.

(11) Wu, J.; Wang, G.; Vijver, M. G.; Bosker, T.; Peijnenburg, W. J. G. M. Foliar versus Root Exposure of AgNPs to Lettuce: Phytotoxicity, Antioxidant Responses and Internal Translocation. Environ. Pollut. 2020, 261, 114117.

(12) Zhao, L.; Zhang, H.; White, J. C.; Chen, X.; Li, H.; Qu, X.; Ji, R. Metabolomics Reveals That Engineered Nanomaterial Exposure in
Soil Alters Both Soil Rhizosphere Metabolite Profiles and Maize Metabolic Pathways. Environ. Sci.: Nano 2019, 6, 1716-1727.

(13) Gao, X.; Avellan, A.; Laughton, S.; Vaidya, R.; Rodrigues, S. M.; Casman, E. A.; Lowry, G. V. CuO Nanoparticle Dissolution and Toxicity to Wheat ( Triticum Aestivum) in Rhizosphere Soil. Environ. Sci. Technol. 2018, 52, 2888-2897.

(14) Zhang, H.; Huang, M.; Zhang, W.; Gardea-Torresdey, J. L.; White, J. C.; Ji, R.; Zhao, L. Silver Nanoparticles Alter Soil Microbial Community Compositions and Metabolite Profiles in Unplanted and Cucumber-Planted Soils. Environ. Sci. Technol. 2020, 54, 3334-3342.

(15) Ge, Y.; Priester, J. H.; Van De Werfhorst, L. C.; Walker, S. L.; Nisbet, R. M.; An, Y.-J.; Schimel, J. P.; Gardea-Torresdey, J. L.; Holden, P. A. Soybean Plants Modify Metal Oxide Nanoparticle Effects on Soil Bacterial Communities. Environ. Sci. Technol. 2014, 48, 13489-13496.

(16) Li, M.; Wang, P.; Dang, F.; Zhou, D.-M. The Transformation and Fate of Silver Nanoparticles in Paddy Soil: Effects of Soil Organic Matter and Redox Conditions. Environ. Sci.: Nano 2017, 4, 919-928.

(17) Guan, X.; Gao, X.; Avellan, A.; Spielman-Sun, E.; Xu, J.; Laughton, S.; Yun, J.; Zhang, Y.; Bland, G. D.; Zhang, Y.; et al. CuO Nanoparticles Alter the Rhizospheric Bacterial Community and Local Nitrogen Cycling for Wheat Grown in a Calcareous Soil. Environ. Sci. Technol. 2020, 54, 8699-8709.

(18) Pradas del Real, A. E.; Castillo-Michel, H.; Kaegi, R.; Sinnet, B.; Magnin, V.; Findling, N.; Villanova, J.; Carrière, M.; Santaella, C.; Fernández-Martínez, A.; et al. Fate of Ag-NPs in Sewage Sludge after Application on Agricultural Soils. Environ. Sci. Technol. 2016, 50, $1759-1768$.

(19) Gao, X.; Spielman-Sun, E.; Rodrigues, S. M.; Casman, E. A.; Lowry, G. V. Time and Nanoparticle Concentration Affect the Extractability of $\mathrm{Cu}$ from $\mathrm{CuO}$ NP-Amended Soil. Environ. Sci. Technol. 2017, 51, 2226-2234.

(20) Zhang, W.; Dan, Y.; Shi, H.; Ma, X. Effects of Aging on the Fate and Bioavailability of Cerium Oxide Nanoparticles to Radish (Raphanus Sativus L.) in Soil. ACS Sustain. Chem. Eng. 2016, 4, 5424-5431.

(21) Samarajeewa, A. D.; Velicogna, J. R.; Princz, J. I.; Subasinghe, R. M.; Scroggins, R. P.; Beaudette, L. A. Effect of Silver NanoParticles on Soil Microbial Growth, Activity and Community Diversity in a Sandy Loam Soil. Environ. Pollut. 2017, 220, 504-513.

(22) Montes de Oca-Vásquez, G.; Solano-Campos, F.; Vega-Baudrit, J. R.; López-Mondéjar, R.; Odriozola, I.; Vera, A.; Moreno, J. L.; Bastida, F. Environmentally Relevant Concentrations of Silver Nanoparticles Diminish Soil Microbial Biomass but Do Not Alter Enzyme Activities or Microbial Diversity. J. Hazard. Mater. 2020, 391, 122224.

(23) Meier, M. J.; Dodge, A. E.; Samarajeewa, A. D.; Beaudette, L. A. Soil Exposed to Silver Nanoparticles Reveals Significant Changes in Community Structure and Altered Microbial Transcriptional Profiles. Environ. Pollut. 2020, 258, 113816.

(24) Grün, A.-L.; Manz, W.; Kohl, Y. L.; Meier, F.; Straskraba, S.; Jost, C.; Drexel, R.; Emmerling, C. Impact of Silver Nanoparticles (AgNP) on Soil Microbial Community Depending on Functionalization, Concentration, Exposure Time, and Soil Texture. Environ. Sci. Eur. 2019, 31, 15.

(25) Schlich, K.; Hund-Rinke, K. Influence of Soil Properties on the Effect of Silver Nanomaterials on Microbial Activity in Five Soils. Environ. Pollut. 2015, 196, 321-330.

(26) Wang, Z.; Yue, L.; Dhankher, O. P.; Xing, B. Nano-Enabled Improvements of Growth and Nutritional Quality in Food Plants Driven by Rhizosphere Processes. Environment International; Elsevier Ltd, 2020; p 105831.

(27) Zhang, R.; Vivanco, J. M.; Shen, Q. The Unseen Rhizosphere Root-Soil-Microbe Interactions for Crop Production. Current Opinion in Microbiology; Elsevier Ltd, 2017; pp 8-14.

(28) Sillen, W. M. A.; Thijs, S.; Abbamondi, G. R.; Janssen, J.; Weyens, N.; White, J. C.; Vangronsveld, J. Effects of Silver Nanoparticles on Soil Microorganisms and Maize Biomass Are Linked in the Rhizosphere. Soil Biol. Biochem. 2015, 91, 14-22. 
(29) Vitali, F.; Raio, A.; Sebastiani, F.; Cherubini, P.; Cavalieri, D.; Cocozza, C. Environmental Pollution Effects on Plant Microbiota: The Case Study of Poplar Bacterial-Fungal Response to Silver Nanoparticles. Appl. Microbiol. Biotechnol. 2019, 103, 8215-8227.

(30) Dai, Y.; Chen, F.; Yue, L.; Li, T.; Jiang, Z.; Xu, Z.; Wang, Z.; Xing, B. Uptake, Transport, and Transformation of $\mathrm{CeO} 2$ Nanoparticles by Strawberry and Their Impact on the Rhizosphere Bacterial Community. ACS Sustain. Chem. Eng. 2020, 8, 4792-4800. (31) Klein, C. L.; Comero, S.; Stahlmecke, B.; Romazanov, J.; Kuhlbusch, T. A. J.; Van Doren, E.; De, P.-J.; Mast, T. J.; Wick, P.; Krug, H.; et al. NM-Series of Representative Manufactured Nanomaterials NM-300 Silver Characterisation, Stability, Homogeneity Study. JRC Scientific and Technical Reports, 2011.

(32) Zhang, X.; Xu, Z.; Qian, X.; Lin, D.; Zeng, T.; Filser, J.; Li, L.; $\mathrm{Kah}, \mathrm{M}$. Assessing the Impacts of $\mathrm{Cu}(\mathrm{OH}) 2$ Nanopesticide and Ionic Copper on the Soil Enzyme Activity and Bacterial Community. ACS Appl. Mater. Interfaces 2020, 68, 3372.

(33) Hui, J.; O’Dell, Z. J.; Rao, A.; Riley, K. R. In Situ Quantification of Silver Nanoparticle Dissolution Kinetics in Simulated Sweat Using Linear Sweep Stripping Voltammetry. Environ. Sci. Technol. 2019, 53, 13117.

(34) Li, X.; Lenhart, J. J.; Walker, H. W. Aggregation Kinetics and Dissolution of Coated Silver Nanoparticles. Langmuir 2012, 28, 1095-1104.

(35) Das, P.; Barua, S.; Sarkar, S.; Chatterjee, S. K.; Mukherjee, S.; Goswami, L.; Das, S.; Bhattacharya, S.; Karak, N.; Bhattacharya, S. S. Mechanism of Toxicity and Transformation of Silver Nanoparticles: Inclusive Assessment in Earthworm-Microbe-Soil-Plant System. Geoderma 2018, 314, 73-84.

(36) Cruz, N. C.; Farto, M.; Mourinha, C.; Tavares, D.; Duarte, A. C.; Trindade, T.; Pereira, E.; Römkens, P. F. A. M.; Alvarenga, P.; Rodrigues, S. M. Dissolution of Ag Nanoparticles in Agricultural Soils and Effects on Soil Exoenzyme Activities. Environments 2021, 8, 22.

(37) Molleman, B.; Hiemstra, T. Time, PH, and Size Dependency of Silver Nanoparticle Dissolution: The Road to Equilibrium. Environ. Sci.: Nano 2017, 4, 1314-1327.

(38) Adamczyk, Z.; Ó́wieja, M.; Mrowiec, H.; Walas, S.; Lupa, D. Oxidative Dissolution of Silver Nanoparticles: A New Theoretical Approach. J. Colloid Interface Sci. 2016, 469, 355-364.

(39) Lowry, G. V.; Espinasse, B. P.; Badireddy, A. R.; Richardson, C. J.; Reinsch, B. C.; Bryant, L. D.; Bone, A. J.; Deonarine, A.; Chae, S.; Therezien, M.; et al. Long-Term Transformation and Fate of Manufactured Ag Nanoparticles in a Simulated Large Scale Freshwater Emergent Wetland. Environ. Sci. Technol. 2012, 46, 7027-7036.

(40) Settimio, L.; McLaughlin, M. J.; Kirby, J. K.; Langdon, K. A.; Lombi, E.; Donner, E.; Scheckel, K. G. Fate and Lability of Silver in Soils: Effect of Ageing. Environ. Pollut. 2014, 191, 151-157.

(41) Carbone, S.; Vittori Antisari, L.; Gaggia, F.; Baffoni, L.; Di Gioia, D.; Vianello, G.; Nannipieri, P. Bioavailability and Biological Effect of Engineered Silver Nanoparticles in a Forest Soil. J. Hazard. Mater. 2014, 280, 89-96.

(42) Li, N.; Li, X.; Shi, Z.-Y.; Fan, X.-Y.; Zhou, Z.-W. Bacterial Communities, Potential Pathogens and Antibiotic Resistance Genes of Silver-Loaded Stainless Steel Pipe Wall Biofilm in Domestic Hot Water System. J. Water Process. Eng. 2021, 40, 101935.

(43) Zeng, X.-Y.; Li, S.-W.; Leng, Y.; Kang, X.-H. Structural and Functional Responses of Bacterial and Fungal Communities to Multiple Heavy Metal Exposure in Arid Loess. Sci. Total Environ. 2020, 723, 138081.

(44) Ge, Y.; Schimel, J. P.; Holden, P. A. Identification of Soil Bacteria Susceptible to $\mathrm{TiO} 2$ and $\mathrm{ZnO}$ Nanoparticles. Appl. Environ. Microbiol. 2012, 78, 6749-6758.

(45) Ward, N. L.; Challacombe, J. F.; Janssen, P. H.; Henrissat, B.; Coutinho, P. M.; Wu, M.; Xie, G.; Haft, D. H.; Sait, M.; Badger, J.; et al. Three Genomes from the Phylum Acidobacteria Provide Insight into the Lifestyles of These Microorganisms in Soils. Appl. Environ. Microbiol. 2009, 75, 2046-2056.

(46) Bergmann, F.; Selesi, D.; Weinmaier, T.; Tischler, P.; Rattei, T.; Meckenstock, R. U. Genomic Insights into the Metabolic Potential of the Polycyclic Aromatic Hydrocarbon Degrading Sulfate-Reducing Deltaproteobacterium N47. Environ. Microbiol. 2011, 13, 1125-1137. 